\title{
DEVELOPING CULTURE-BASED ENGLISH LANGUAGE ASSESSMENT INSTRUMENT FOR SECOND SEMESTER OF GRADE SEVEN OF JUNIOR HIGH SCHOOL IN BULELENG SUB-DISTRICT TO SUPPORT THE IMPLEMENTATION OF CURRICULUM 2013
}

\author{
I. A.U. Wasundari ${ }^{1}$, N. K. A. Suwastini ${ }^{2}$, I. G. Batan ${ }^{3}$ \\ Jurusan Pendidikan Bahasa Inggris \\ Universitas Pendidikan Ganesha \\ Singaraja, Indonesia
}

\begin{abstract}
e-mail :utariwasundari@gmail.com ${ }^{1}$, ariesuwastini80@gmail.com² $^{2}$, igdbatan@yahoo.com ${ }^{3}$
\end{abstract}

\begin{abstract}
Abstrak
Penelitian ini bertujuan untuk mengembangkan instrumen penilaian berbasis budaya untuk semester genap kelas VII SMP di Kecamatan Buleleng untuk mendukung implementasii Kurikulum 2013.Penelitian ini dikategorikan sebagai penelitian dan pengembangan.Model dari penelitian dan pengembangan yang digunakan pada penelitian ini yaitu model penelitian dan pengembembangan oleh Peffers et al. (2007).Penelitian ini berdasarkan penelitian sebelumnya yang telah dilakukan oleh Dewi dan Batan (2015). Instrumen penilaian Bahasa Inggris yang cocok untuk semester genap kelas VII SMP di Kabupaten Buleleng yaitu instrumen penilaian yang mengintegrasikan budaya lokal untuk mendukung pengembangan karakter siswa.Langkah-langkah pengembangan instrumen penilaian ini meliputi analisis tujuan, analisis standar penilaian, analisis silabus, analisis sumber bahan ajar, mendesain kisi-kisi, pengembangan instrumen penilaian, penilaian ahli, dan revisi.Pengembangan penilaian ini menghasilakan instrumen penilaian Bahasa Inggris yang digunakan untuk menilai ranah afektif, cognitif, dan psikomotor.Reliabilitas dan kualitas dari instrument penilaian yang telah dikembangakan diperoleh dengan memberikan lembar penilaian untuk ahli penilaian dan ahli pembelajaran Bahasa inggris.Nilai yang diberikan oleh kedua ahli yaitu ahli pertama memberikan nilai sebesar 650 dan ahli kedua memberikan nilaii sebesar 802.Berdasarkan hasil tersebut, kualitas instrumen peniaian yaitu sangat baik. Reliabilitas instrumen penilaian juga dikategorikan sangat baik dimana nilai dari Alpha Cronbach's coefficient sebesar 0,9. Hal ini menunjukkan bahwa instrumen penilaian cocok digunakan dalam proses pembelajaran Bahasa Inggris di sekolah yang mengimplementasikan Kurikulum 2013.
\end{abstract}

Kata Kunci: Budaya Bali, Penilaian Bahasa Inggris, dan Kurikulum 2013

\begin{abstract}
This research aimed at developing culture-based English language assessment instrument for the second semester of grade seven of junior high school in Buleleng Subdistrict to support the implementation of Curriculum 2013. This research was categorized as research and development $(\mathrm{RnD})$. Research and development model which was used in this research proposed by Peffers et.al (2007). This research was based on previous research which had been conducted by Dewi and Batan (2015). The suitable English assessment for the second semester of grade seven of junior high school was English assessment with integrated Balinese culture in order to support the development of character building. The steps of developing this English assessment instrument included assessment goal analysis, assessment standard analysis, syllabus analysis, learning source analysis, designing blue print, developing assessment, expert judgment, and revision. This research produced English assessment instrument which assessed students' affective, cognitive, and psychomotor domains. The reliability and quality of the developed assessment instrument were found out by giving expert judgment form to the experts of assessment and English language teaching. The scores which were given by
\end{abstract}




\begin{abstract}
the two experts were 650 from the first expert and 802 from the second expert. Based on those scores, the quality of the developed English assessment instrument was categorized as excellent. The reliability of the data was categorized as excellent in which the score of Alpha Cronbach's coefficient was 0.9. It means that the developed culturebased English assessment instrument was suitable to be used in teaching and learning process that implements Curriculum 2013 in Buleleng Sub-district.
\end{abstract}

Keywords: Balinese culture, English assessment, and 2013 Curriculum

\section{INTRODUCTION}

Preparation, implementation, and assessment of teaching and learning process should be given more attention by the teacher in order to administer the teaching process successfully. It is also regulated by Peraturan Kementerian Pendidikan dan Kebudayaan No. 65 Tahun 2013 (Regulations of the Ministry of Education and Culture, number 65, Year 2013), which explains the standard of process for primary and secondary school in Indonesia. It is very important to consider the preparation before teaching, how to implement the preparation, and how to assess the learning as well. The implementation of assessment in teaching and learning process is very essential in order to be able to determine whether or not the goal of education has been achieved.

According to Peraturan Kementerian Pendidikan dan Kebudayaan, No. 64, Tahun 2013 (Regulations of the Ministry of Education and Culture number 64 year 2013), about Standard of Process, by assessing students' attitude, teacher can control students' bad behaviors and give warning for students' misbehaviors. Then, the students may change their bad behaviors into good behaviors.

Related to the importance of assessing students' learning, assessment in education has close relationship to character building. Undang-Undang No. 20, Tahun 2003, Pasal 3 (Law No. 20 Year 2003, article 3), about National Education System, states that National Education has several functions, such as to build and develop character in order to create intelligent person for the better nation

Based on the interview that have been conducted by Dewi and Batan (2015) with
English teachers of grade seven in seven junior high schools in Buleleng Sub district, the researcher got information that character education was taught in every lesson by inserting it during the learning process. Teachers thought that character education was very important to be inserted in every lesson because they are still in unstable age and their behaviors were easily provoked by others. Beside the character education, the teachers also supported the insertion of local culture every lesson, especially English.

In addition, according to Dewi and batan (2015), all of English teachers of grade seven of junior high school in Buleleng Sub district said that local culture was very important to be inserted in English subject because the values of local culture can increase students' awareness toward the problems which happened around them. But, nowadays, local culture tends to be forgotten and may be lost. Dewi and Batan (2015) state that the fact happened because the development of technology is not accompanied by the character education and local culture itself. The local culture day by day will be shifted by the modern life.

This present research was conducted based on the previous research about the importance of inserting local culture in English assessment instruments in order to develop students' character which has been done by Dewi and Batan (2015). The statement of problem of the present research was "What items are required to develop culture-based English language assessment instrument for second semester of grade seven of junior high school in Buleleng Sub-district to support the implementation of Curriculum 2013?". Related to the statement of the problem, the purpose of this present research was 
developing culture based English assessment instruments for second semester of grade seven of junior high school, especially in Buleleng sub district. This product supported the implementation of Curriculum 2013 in order to build and develop the good character building. This research could also help the English teacher and students in junior high school to improve their teaching skill and can help the students in developing their character building. This product was used to support the implementation of Curriculum 2013 for the schools which had been used Curriculum 2013 and could be used to help the schools which did not implement Curriculum 2013 yet in preparing the change from School Based Curriculum into Curriculum 2013. In addition, the developed product of this present study was used as supplementary in teaching and learning English as foreign language. It could be used by teachers when they wanted to teach English with inserting positive local culture values.

\section{LITERATURE REVIEW}

According to Johnson and Johnson (2002:6) assessment is a process of collecting information about the quality of a change of a student, group, teacher, or administrator. Furthermore, Mousavi (2009, in Brown, 2010:3), defines assessment as appraising or estimating the level or magnitude of some attribute of person. Brown (2010:3) also states that assessment is an ongoing process that encompasses a wide range of methodological techniques. Teacher will make an appraisal unconsciously whenever the student's respond a question, offers a comment, or tries out a new word or structure.

The purpose of teaching English in Curriculum 2013 is teaching English as a foreign language and second language. According to Kosasih (2014:131), to assess students' level in learning English as a foreign language in Curriculum 2013 use authentic assessment. Authentic assessment is another characteristic of Curriculum 2013. In 2013 Curriculum, there are some techniques used in assessing students' attitude during the learning process. Based on Regulation of the Ministry of Education and Culture, number 66, Year 2013, teachers should assess students' attitude by doing observation during the teaching and learning process, giving self-assessment sheet to the students and giving peer assessment sheet to the students. The instruments used in observation, self assessment, and peer assessment are rating scale including rubric, and teacher's journal. Then, to assess students' knowledge or cognitive domain by written test, oral test, and task. Moreover, teachers should assess students' skill through students' performance. The students are demanded to demonstrate each skill through practice test, project, and portfolio assessment.

Since this research focused on integrating Balinese local culture, there are several positive Balinese culture values which are used in developing this English assessment instrument, namely (1) Brahman, a concept that sees God is everything and everything that exists in this universe is God, (2) Brahmacari, the age when people find and learn knowledge in order to be able to be used in their life, (3) Swadharma, individual duties and everyone should responsible to his/her own duties, (4) Jemet, an attitude to be discipline and diligent person, (5) Jengah, an attitude which shows individual effort in working, (6) Menyama Braya, relationship among people in society as a symbol of tolerance and solidarity, (7) De Koh Ngomong, an attitude to think critically, communicatively, and be friendly, (8) Segilik-seguluk, a willing to do tasks by working together, (9) Salunglung sabayantaka, living in harmony in good and bad times, (10) Pasidikaran, a willing of people in society to do works together, (11) Ruang Musuhin, a value of Balinese culture that cover honesty, open minded, sincerity, and believing others.

Meanwhile, character education has five goals (Zubaedy, 2013:72). The goals are to develop the potential of students as a human and citizen that have good character or morality, to develop the 
students' habit and behavior which is good and in line with the universal values and cultural tradition, to develop students' leadership and responsibility as the next generation of the nation, to develop the students' competency to be independent, creative, and knowledgeable person, and to build the learning environment become creative, good friendship, honest, safe, and feel dignity.

Based on 18 Karakter Bangsa ( 18 character building of nation) (Diknas in Zubaedi, 2011:74-76), the values of character education can be divided into eighteen values, namely 1) Religious, it means attitude and behavior which obediently do religion precept, tolerant with people which have different religion, and live in harmony with people who have different religion. 2) Honesty, the attitude in which people try to make themselves trusted by other people. 3). Tolerance, it is the attitude of being respect to the differences around including religions, opinions, ethnicities, and other else which are different. 4) Discipline, it is the attitude of obeying the rules and policies. 5) Hard work, the attitude that indicates serious efforts in handling the obstacles in learning and efforts in doing the works well. 6) Creative, create something new based on the things that have been owned. 7) Independent, the attitude which does not depend on other people in doing the assignments or works. 8) Democracy, the way of thinking and action that all people have same rights and obligations. 9) Curiosity, the attitude in which people want to know everything and try to explore more something deeper that they have studied, heard, and seen. 10) Spirit of Nationalism, the attitude that puts the importance of nation over the importance of self and group. 11) Patriotism, the way of thinking and acting to appreciate and to be loyal to the language, physical environment, social, cultural, economic, and political of nation. 12) Recognize Excellent, the attitude of creating something useful and beneficial for others and being respect of others' success. 13) Friendly / Communicative, the attitude to mingle with others. 14) Love Peace, the attitude of efforts to make other people feel happy and secure. 15) Love Reading, the attitude to read various kinds of reading which are beneficial. 16) Environmental caring, the attitude to prevent the damage of environment and to develop the action to heal the damage of environment. 17) Social Caring, the attitude to help other people who need helps. 18) Responsibility, the attitude to carry out the tasks or assignments that they should do.

In addition, based on Panduan Pendidikan Karater untuk SMP (Guidance of Character Education for Junior High School) (Ministry of National Education, 2010), there are three additional values of character which should be developed by the students. They are confidence, entrepreneurship, and healthy life style. Confidence means an attitude which make someone have self confident or convinced of everything that they do. Meanwhile, entrepreneurship is an attitude to be independent, smart, and talented to find out something new, determine a way to produce something new, arrange an action to supply new product, then distributed it and manage the financial capital. The last character is healthy life style. It is an effort to apply good habit in order to build healthy life and avoid bad habit which can disrupt health.

There were three empirical reviews which were related to the present study, namely first, Sudartini (2012) has conducted research about inserting local culture in English language teaching to promote character education. The result of this study is English language teaching cannot be separated from culture and by considering the need to maintain the nation identity. It is also beneficial to insert the local cultural values and norms in the practice of English language teaching. Second, Kanoksilapatham (2015) has conducted research about the positive impact of integrated instruction of local culture and global English in Thailand. The result of this study is the students had significantly higher gain scores regarding the knowledge of their local culture and were able to successfully perform the role of a tour guide at the monastery. Third, Doganay, Ashirimbetova \& Davis in 2013 have 
conducted research which is aimed at examining the effect of culture and investigating the attitudes of students towards language teaching and learning through culture-based activities both local and target culture. The results suggest that practice of the various culture-based tasks and exercises helped the students to improve their communicative and linguistic competences in English.

\section{METHOD}

This research took place in all junior high school in Buleleng Sub district, such as SMP N 1 Singaraja, SMP N 2 Singaraja, SMP N 3 Singaraja, SMP N 4 Singaraja, SMP N 5 Singaraja, SMP N 6 Singaraja, SMP N 7 Singaraja, SMP Laboratorium UNDIKSHA, and SMP Mutiara Singaraja.

The subjects of this study were students and English teacher of second semester of junior high school grade VII where the study taken place. The object of this study was culture based English assessment for grade seven of second semester of junior high school which was developed by the researcher in order to support the implementation of Curriculum 2013.

This research was categorized as research and development. Research and development was a research method which was used to produce something (Sugiyono, 2013:407). To be able to produce a product, it used need analysis and expert judgment. This research applied the adaptation of research and development by Peffers (2007) as cited in Ellis and Levy (2010). There were 6phases of research and development model by Peffers. Those phases were a) identify the problem motivating the research; b) describe the objectives; c) design and develop the artifact; d) subject the artifact to testing; e) evaluate the results of testing; and f) communicate those results.

There were some instruments in collecting the data. In this research, the researcher used several kinds of instruments namely document, field note, and expert judgment. Document was one of the instruments used by the researcher.
Document was used by researcher to collect the data. The document which was analyzed in this research were syllabus of grade seven of junior high school and assessment standard in Curriculum 2013. Field Note was used to take a note everything which are important related to the research. From this note, the researcher got additional information to complete the research. The last instrument was expert judgment form. The form was designed based on the criteria of good assessment. This form was given to the expert to check out whether or not the assessment suitable to be used.

The collected data were analyzed both descriptive qualitative and quantitative. The culture based English assessment explained qualitatively, and then the result of expert judgment from the experts was analyzed quantitatively by using SPSS 16 . The reliability of the developed assessment instruments were found out by using Cronbach's Alpha coefficient and processed by using SPSS 16. Meanwhile, to interpret the meaning of the Cronbach's Alpha coefficient used categories of data reliability by George and Mallery (2003) in Gliem and Gliem (2003).Then, the quality of developed assessment instruments were found out by using formula by Nurkancana and Sunartana (1992).

\section{FINDINGS}

There were several things which were explained in finding, namely the result of analyzing assessment standard of Curriculum 2013, the result of analyzing English syllabus for second semester of grade seven of junior high school, the result of goal analysis, the development of assessment instrument for second semester of grade seven of junior high school, and the quality of the English assessment instrument design.

First of all, the researcher conducted assessment standard analysis to identify need of developed English assessment instrument for second semester of grade seven of junior high school. This analysis focused on the general standard of assessment process in Curriculum 2013. The general standard of assessment in Curriculum 2013 was 
based on Peraturan Kementerian Pendidikan dan Kebudayaan No. 66, Tahun 2013 (Regulation of the Ministry of Education and Culture, number 66, Year 2013), about Assessment Standards. The result of assessment standard analysis was the assessment of students' achievement includes cognitive, affective, and psychomotor domains. Each domain was assessed by using different assessment procedure. Affective domain could be assessed by four assessment procedures namely observation, self assessment, peer assessment and teacher's journal. While assessing students' cognitive domain, the teacher canuse written test, oral test, and task. For assessing students' language skills, the teachercan use project, portfolio, and performance assessment types. In conclusion, based on the result of assessment standard analysis, the developed assessment instrument involved these kinds of assessment procedure.

After analyzing the assessment standard, the researcher conducted analysis to the syllabus. Syllabus for second semester of grade seven became guidance in developing these assessment instruments. Based on the syllabus, it was found that there were four core competencies in the Curriculum 2013, namely core competency 1 and core competency 2 for affective aspect, core competency 3 for knowledge or cognitive aspect, and core competency 4 for skill or psychomotor aspect. Those core competencies developed into several basic competencies. While for second semester there were one basic competency found for core competency 1 $(K I 1)$, three basic competencies for core competency 2 ( $K I$ 2), five basic competencies for core competency 3 (KI $3)$, and seven basic competencies for core competency 4 (KI 4).

The third step was assessment goal analysis. Based on the analysis, it was decided that the aim of this assessment was to provide the assessment instrument which inserting local culture values to support the development of student's character. The developed assessment instruments became supplementary for English teaching and learning process in second semester of grade seven of junior high school. These assessment instruments could be used by the teacher who wanted to teach English with accommodating local culture values.

The fourth step was assessment development. In assessment development, the first step was deciding the suitable themes which covered all materials in second semester of grade seven. The basic competencies in the second semester of grade seven were divided into four themes. The themes were visiting a temple, Nyepi Day, Galungan Festival, and Tumpek Uduh and Tumpek kandang. All of the basic competencies in the second semester of grade seven were included in these four themes. The second step in assessment development was deciding inserted Balinese culture values and character values. The relevance of the Balinese culture values with the character values was found out by conducting analysis panel. The relevance of local culture values with the character values was done by the expert of culture, Dr. Luh Putu Sendratari, M.Hum. Based on the result of validation, there were twenty character values which were developed and fourteen Balinese culture values inserted in the developed assessment instruments. The results were 1) the appropriate culture value for religious character was Brahman, 2) the appropriate culture value for discipline character was Jemet, 3) the appropriate culture values for curious and love to read characters was Brahmacari, 4) the appropriate culture values for spirit of nationalism was segilik seguluk and menyama braya, 5) the appropriate culture value for hard working was jengah, 6) the appropriate culture value for responsibility character was swadharma, 7) the appropriate culture value for love peace, environmental caring, and healthy life style characters was Tri Hita Karana, 8) the appropriate culture value for honest was Tri Kaya Parisudha, 9) the appropriate culture value for tolerant, social caring, and recognize excellent characters was Tat Twam Asi, 10) the appropriate culture value for 
friendly/communicative character was $D e$ Koh Ngomong, 11) the appropriate culture value for confident character was Maitri, 12) the appropriate character value for creative character was Balinese art, 13) the appropriate culture value for independent and democratic characters was Jele melah wenang sambat, and 14) the appropriate culture value for patriotism character was Bani meli bani ngadep.

The development of the assessment instruments was begun after the blue print was designed. The development of assessment instruments was done from developing the content of the assessment instruments, designing the layout and cover, until the guidance of using this assessment instrument handbook. There were two kinds of developed assessment instrument namely English assessment handbook for teacher and English assessment handbook for students. The English assessment handbook for the teacher was the same as a master book.

The content of the assessment handbook was developed based on the general blue print which has been developed. Based on the blue print, the assessment instruments in every theme consisted of three parts namely part 1, part 2, and part 3. Part 1 contained assessment instruments which were used to assess students' affective domain, Part 2 contained assessment instruments which were used to assess students' cognitive domain, and Part 3 contained assessment instruments which were used to assess students' psychomotor domain.

Part 1 was used to assess students' attitude during the class consisted of observation checklist, self assessment checklist, and peer assessment checklist. The integration of Balinese culture values was presented in the items of those checklists. Core competency in this part consisted of core competency 1 and 2 . The observation checklist, Self assessment checklist, and Peer assessment checklist were used ten Balinese culture values and eleven character values namely Brahman for developing religious character, Tri Kaya Parisuda for developing honest character, Jemet for developing discipline character,
Swadharma for developing responsibility character, Jengah for developing hard working character, Brahmacari for developing curious character, Tat Twam Asi for developing tolerant and social caring characters, De Koh Ngomoh for developing friendly/communicative character, Maitri for developing confident character, and Tri Hita Karana for developing environmental caring character. These Balinese culture values were presented into 32 items in observation, self assessment, and peer assessment checklists. These checklists were appeared in every theme. Observation checklist was filled by the teacher. This checklist was used as guidance for the teacher in assessing students' attitude during the classroom activities. This checklist used four scales in which score 4 means always, score 3 means often, score 2 means seldom, and score 1 means never. Meanwhile, for self assessment and peer assessment checklists were filled by the students themselves. By giving self assessment checklists, the students have a chance to assess their own attitude honestly. While peer assessment checklist gave the students chance to assess their friend's attitude during the classroom activities.

Part 2 was used to assess students' cognitive domain included written test and oral test. Core competency involvedin this part was core competency 2 which concerned with knowledge that was gained by the students. The integration ofBalinese culture in this part was presented through the content of the test. The examples were pictures of things around the temple and things related to the Balinese Holy day. Furthermore, kinds of assessment form in the written test developed namely labeling, matching, writing sentence, and writing description. Meanwhile for assessment form in the oral test included present a dialogue in front of the class and reporting the result of interview. In addition, this part was complemented with key answers and also the rubric for each test.

Part 3 concerned with students' psychomotor domain consisted of two kinds of assessment procedures namely 
project and portfolio. This part was designed based on the core competency 3 which focused on students' skill in using English. In this part, students had a chance to show their ability in applying the knowledge that they had gained. Balinese culture was inserted through the activity of completing the project, for example the project in chapter 2; the students were asked to observe warnings which were related to Nyepi Day. The product of project was a poster which would be sticked on the classroom wall. There were three phases for procedure of the project namely planning phase, developing phase, and a final phase. The criteria that should be fulfilled by the students and rubric for project were also complemented in this part. Beside Project, the developed assessment instrument used portfolio to assess students' psychomotor domain. The portfolio appeared in chapter 4 . This part consisted of the procedure of making portfolio. The students were given certain time to finish their portfolio. They were asked to make two kinds of writing, and then chose the best writing to be submitted at the end of the class. There were five steps in completing the porfolio, namely outlining, drafting, revising, editing, and publishing. Similar to the project, this portfolio also included self assessment checklist for the student. This self assessment checklist contained several aspects namely the content, organization, grammar, vocabulary and mechanism. There were 12 items that should be fulfiiled by the students.

The assessment model which had been developed should be judged by the expert to find the quality of the developed assessment instrument. The expert judgment was done by two lectures of Ganesha University of Education, namely Prof. Dr. A. A. Istri Ngurah Marhaeni, M.A. and A. A. Gede Yudha Paramartha, S.Pd., M.Pd. They were chosen because their expertise in the English education area, especially for the assessment.

The experts were given expert judgment form which contained three dimensions namely reliability, validity, and practically. This expert judgment form was divided into eleven parts. They were expert judgment form for observation checklist, self assessment checklist, peer assessment checklist, written test, oral test, project based assessment, self assessment for project, peer assessment for project, portfolio based assessment, self assessment for portfolio, and design. Totally there were 211 items which were measured by using likert scale; score 1 for poor, score 2 for average, score 3 for good, and score 4 for very good. According to the two experts, the quality of the developed assessment instrument was categorized as excellent quality. It was showed by the total score given by each expert was higher than 641.67. In short, the developed English assessment instrument is suitable to be applied in English teaching and learning process for second semester of grade seven.

\section{DISCUSSION}

This research used research and development method which aimed at developing culture-based English assessment instrument to support the character building based on the implementation of 2013 curriculum. It was focused on developing English assessment instrument for second semester of junior high school. This assessment instrument was used to collect students' information during the teaching and learning process. According to Johnson and Johnson (2002), assessment is a process of collecting information about the quality of a change of a student. It means that assessment is used to know about students' achievement during the teaching and learning process. Therefore, assessment was very important to be conducted in order to know whether or not the goal of teaching and learning process has been achieved. Since those functions of assessment in teaching and learning process, the developed assessment instrument already developed in order to help teacher in assessing students' learning.

This present research used model of research and development which proposed by Peffers (2007). Based on Peffers's model, there were six steps in developing product. Therefore, this 
research already conducted those steps. First step was identifying the problem which was conducted by analyzing the assessment standard and syllabus. The result was used as the guidance in developing the assessment instrument. The second step was described the objective which was conducted by analyzing the goal of developed assessment instrument. The result was the developed assessment instrument used as supplementary in teaching and learning process. The third step was designing and developing the assessment instrument. In this steps there were five steps namely deciding theme and indicator, analyzing the integration of Balinese culture values and character values, analyzing learning sources, developing blue print, and developing blue print into assessment instrument. The fourth and fifth steps was finding out the quality and revising the product. This research did not conduct the last step, communicating the product, because the aim of this research was only developing the product. Therefore, this research was developed until the fifth step of Peffers' model.

According to Budhiyani, et al. (2010) assessment in learning process should monitor and measure every aspects of learning result includes cognitive, affective, and psychomotor domains. In line with that statement, this assessment instrument was developed by considering this concept. This assessment instrument was developed to assess students' affective, cognitive, and psychomotor domains. In addition, based on Regulation of the Ministry of Education and Culture, number 66, Year 2013, about Assessment Standards, assessment in Curriculum 2013 focused on those three aspects of students. Therefore, this assessment instruments consisted of three parts in every theme namely part 1 for assessing students' attitude, part 2 for assessing students' knowledge or students understanding toward the lesson of every theme.

As stated in Curriculum 2013, to assess students' affective domain there were three assessment instruments, namely observation checklist, self assessment checklist, and peer assessment checklist. Then, to assess students' cognitive domain, the teachers can give written test, oral, test or task. For written test, it can be given in form of matching, labeling, multiple choice, or short answer question. While, to assess students' psychomotor domain, there were three assessment instruments used, namely performance, portfolio, and project. Therefore, this assessment instruments were developed by involving observation checklist, peer assessment checklist, and self assessment checklist for assess students' attitude. Written test such as matching, labeling, and short answer question were provided to collect the information about students understanding toward the material. Furthermore, for assessing students' skill in English, this assessment instruments used project and portfolio.

In addition, this assessment instrument was used both for authentic and non-authentic assessment. According to O'Malley \& Pierce (1996), the term authentic assessment is used to describe the multiple forms of assessment that reflect student learning, achievement, motivation, and attitudes. The examples of authentic assessment involved performance test, portfolios, and student self-assessment. Meanwhile Frey et al. (2012) stated that non-authentic assessment is usually called as traditional assessment. The examples involved multiple choice, matching, cloze, etc.

Remembering that the development of this assessment instruments was integrating local culture values, there were several Balinese culture values inserted in the assessment instruments. Those Balinese culture values were (1) Brahman which stand for religious person, (2) Jemet which was used to develop discipline, (3) Brahmacari which was used to develop curious and love reading, (4) Jengah was used to develop hard working character, (5) Swadharma was used to develop responsibility, (6) Tri Kaya Parisudha which was used to develop honesty, (7) Maitri was used to develop students' confidence (8) Segilik Seguluk, Menyama Brama, Salunglung Sabayantaka, were used to build spirit of nasionalism, (9) Tri 
Hita Karana was used to develop love peace, environmental caring, and healthy life style, (10) Tat Twam Asi and Rwa Bhineda were used to develop students' tolerant and social caring, (11) Tri Hita Karana was used to develop environmental caring, (12) De Koh Ngomong was used to develop communicative/ friendly (13) Balinese arts were used to develop students' creative, (14) Jele Melah Wenang Sambat and Lascarya were used to build of independent character, (15) Ruang Musuhinwas used to build democratic character, and the last (16) Bani Meli Bani Ngadep was used to develop patriotism.

In addition, according to Marhaeni et al, (2010), the accommodation of culture is important in learning process. In this assessment instrument, Balinese culture was used in every chapter. There were four themes namely visiting temple, Galungan festival, Nyepi Day, and Tumpek Uduh and Tumpek Kandang. The Balinese culture was also inserted through the use of pictures which related to the Balinese culture.

Moreover, this assessment instrument also aimed at supporting character building through the integration of local culture. The character values, which were developed in this assessment instruments, were eighteen characters based on 18 characters of the nation and three additional characters which were taken from Guidance of Character Education for Junior High School. This development of character building in the assessment instrument was based on Elkin and Sweet (2004) in Zubaedi (2011) who stated that character education is the deliberate effort to help people to understand, to care about, and to act upon core ethical value.

This developed assessment instrument had been found out the reliability and quality which was conducted by the experts. The reliability and quality of the developed assessment instrument were found out by giving expert judgment form to the judges. This expert judgment form divided into eleven parts. The eleven parts were judgment form for observation checklist, self assessment checklist, peer assessment checklist, written test, oral test, project, self assessment for project, peer assessment for project, portfolio, self assessment for portfolio, and design and layout. Totally there were 210 items which were measured by using Likert scale; score 1 for poor, score 2 for average, score 3 for good, and score 4 for very good. Total scores given by the experts were 605 and 850 . These score were analyzed by using SPSS 16 and Cronbach's Alpha coefficient to find out the reliability of the product. The result of Cronbach's Alpha was 0.99. To interpret the meaning of this result of Cronbach's Alpha, the researcher used six categories of reliability data propose by George and Mallery (2003, in Gliem and Gliem, 2003). Based on those six categories, the reliability of developed assessment instrument was categorized as excellent. Meanwhile, the scores given by the expert were analyzed by using formula which is proposed by Nurkancana and Sunartana (1992). The result of analyzing the expert judgment form by using formula which is proposed by Nurkancana and Sunartana (1992), it was found that the score given by the experts was higher than 641.67. The result showed that the quality of the developed assessment instrument was categorized as excellent. Since the purpose of doing expert judgment toward the developed assessment instruments was to find out whether this developed assessment instrument was suitable used, therefore, in accordance which the result of reliability and quality from the expert, this developed assessment instrument was suitable to be used in English teaching and learning process for second semester of grade seven of junior high school.

This developed assessment instrument was already revised based on the correction and suggestion from the experts. There were some correction from the expert toward the developed assessment instrument, such as correction in the use grammar, word order and rubric. The correction from the expert made the developed assessment instrument was better than before.

In conclusion, this developed assessment instrument could be used by the English teacher as supplementary. The teacher who wanted to teach English 
by inserting Balinese culture values could use this assessment instrument in teaching and learning process. In addition, this developed assessment instrument could be used to developed character building of the students.

\section{CONCLUSION}

Thisresearch was conducted to develop supplementary English assessement instruments which accommodatelocal culture to support character building based on the implementation of Curriculum 2013. The Assessment instruments involved three parts of students' domain namely affective, cognitive, and psychmotor. Since the assessment intruments were integrated local culture values, there were several local culture values inserted in the instruments. These local culture values were used to support the development of character buildings. The character building used in these instruments was based on eighteen character building of the National Education. This research was used reasearch and developmet model of Peffers. Meanwhile in developing assessment instruments, there were several steps including identify the goal of assessement, then, analyze syllabus, analyze textbook and other sources, design blue print of assessment, develop the blue print into assessment instrument, validation, and revision. In addition, the quality of the developed assessment instruments was categorized as excellent quality since the score given by the experts were 650 and 802 . The result of this study showed that the developed assessment instruments was appropriate to be used in English teaching and learning process for second semester of grade seven of junior high school in Buleleng sub-district to support the implementation of Curriculum 2013.

\section{REFERENCES}

Brown, H. D. (2010). Language Assessment: Principles and Classroom Practices. United States of America: Pearson Education.
Budhyani, D. A., Ariani, R. P., Adnyawati, D. M., Sukerti, N. W., \& Widiartini, N. K. (2010). Evaluasi dan Asesmen Hasil Belajar. Singaraja: Jurusan Pendidikan Kesejahteraan keluarga Fakultas Teknik dan kejuruan Universitas Pendidikan Ganesha Singaraja.

Dewi, N. L.P.E, \& Batan, I.G. (2015). Pengembangan Suplemen Perangkat Pembelajaran Bahasa Inggris Berwawasan Budaya Bagi SMP Kelas VII untuk Menunjang Pengembangan Karakter Bangsa. UNDIKSHA:Laporan Penelitian.

Doganay, Y., Ashirimbetova, M., \& Davis, B. (2013).Making Culture Happen in the English Language Classroom.English Language Teaching.6(10). doi:10.5539/elt.v6n10p11. Retrieved from

http://www.ccsenet.org/journal/index .php/elt/article/view/30157/17864.pdf

Ellis, T. J., \& Levy, Y. (2010). A Guide for Novice Researchers: Design and Development Research Methods. Retrieved from http://proceedings.informingscience. org/InSITE2010/InSITE10p107118Ellis725.pdf

Frey, B.B., Smith, V.L., \& Allen, J.P. (2012).Defining Authentic Classroom Assessment.Practical Assessment, Research, \&Evaluation.17(2).SN 1531-7714. Retrieved from http://pareonline.net/getvn.asp?v=17 $\underline{\&=2}$

Gliem, J.A. \& Gliem, R.R.(2003). Calculating, Interpreting, and Reporting Cronbach's Alpha Reliability Coefficient for Likert-Type Scales.2003 Midwest Research to Practice Conference in Adult, Continuing, and Community Education. Retrieved from 
http://www.ssnpstudents.com/wp/wp -content/uploads/2015/02/GliemGliem.pdf

Johnson, D. W. \& Johnson, R. T. (2002).Meaningful Assessment: A Manageable and Cooperative Process. Boston: A Pearson Education Company.

Kanoksilapatham, B. (2015). Developing Young Learners" Local Culture Awareness and Global English: Integrated Instruction. International Journal of Information and Education Technology.5(9).doi: 10.7763/IJIET.2015.V5.591.

Retrieved from http://www.ijiet.org/papers/591$\underline{\text { J00016.pdf }}$

Kementerian Pendidikan dan Kebudayaan.(2014). Modul Pelatihan Implementasi Kurikulum 2013.Jakarta:

Badan Pengembangan Sumberdaya Manusia Pendidikan dan Kebudayaan dan Penjaminan Mutu Pendidikan.

Kementerian Pendidikan Nasional (2010) Panduan Pendidikan Karakter di Sekolah Menengah Pertama. Retrieved from http://repository.unand.ac.id/22742/1 14 PANDUAN PELAKS PENDIDIK AN KARAKTER.pdf

Kosasih, E. (2014). Strategi Belajar dan Pembelajaran Implementasi Kurikulum 2013.Bandung: Yrama Widya

Marhaeni, A. N., Koyan, W., \& Ramendra, D. P. (2010). Pengembangan Perangkat Asesmen Kinerja sebagai Asesmen Proses dan Produk dalam Implementasi Kurikulum Tingkat Satuan Pendidikan (KTSP) Mata Pelajaran Bahasa Inggris di SMA. Singaraja: Undiksha.
Nurkancana, Wayan \& Sunartana.(1992). Evaluasi Hasil Belajar.Surabaya : Usaha Nasional.

O'Malley, J. M., \& Pierce, C. V. (1996). Authentic Assessment for English Language Learners. USA: Addison-Wesley Publishing Company.

Permendikbud Nomor 64 Tahun 2013 tentang Standar isi. Retrieved from http://www.pendis.kemenag.go.id/pa i/file/dokumen/06.B.SalinanLampira nPermendikbudNo.64th2013ttgStand arIsi.pdf

Permendikbud No. 65 Tahun 2013 tentang Standar Proses. Retrieved from http://www.pendis.kemenag.go.id/pa i/file/dokumen/07.A.SalinanPermend ikbudNo.65th2013ttgStandarProses. pdf

Permendikbud No. 66 Tahun 2013 tentang Standar Penilaian. Retrieved from https://akhmadsudrajat.files.wordpre ss.com/2013/06/04-a-salinanpermendikbud-no-66-th-2013-ttgstandar-penilaian.pdf

Sudartini, S. (2012) Inserting Local Culture in English Language Teaching to Promote Character Education.

JurnalPendidikanKarakter. 45-54. ISSN: 2089-5003. Retrieved from http://journal.uny.ac.id/index.php/jpk a/article/view/1451

Sugiyono. 2013. Metode Penelitian Kuantitatif, Kualitatif, dan $R \& D$. Bandung: Alfabeta.

Undang-Undang No. 20, Tahun 2003, Sistem Pendidikan Nasional.Retrieved from 
http://sipma.ui.ac.id/files/dokumen/ U_SNP_SN\%20PT/PP\%20SNP/PP0 322013_SNP.pdf
Zubaedi. (2013). Desain Pendidikan Karakter:Konsepsi dan Aplikasinya dalam Lembaga Pendidikan.Jakarta:Kencana Prenada Media Group. 